\title{
A VIRTUAL LABORATORY APPLICATION FOR VOCATIONAL PRODUCTIVE LEARNING USING AUGMENTED REALITY
}

\author{
Pratama Benny Herlandy, Januar Al Amien, Pahmi Pahmi, and Agus Satria \\ Universitas Muhammadiyah Riau, Indonesia \\ E-mail: pratamabenny@umri.ac.id
}

\begin{abstract}
The objectives of this study were (1) to produce a virtual laboratory application for vocational productive learning by applying Augmented Reality technology; (2) to examine the validity of the developed application from the aspects of media development and productive learning materials. The method used in this study was research and development with the waterfall model. The stages of development included needs analysis, design, implementation, and system testing. The result of the development was the learning application called AugWare operated using an Android smartphone. The application was equipped with the features of learning materials, simulation and evaluation. The results of validation by media experts through an assessment questionnaire consisting of 32 items revealed that the average final score was 84 categorized as very appropriate. In the assessment of material experts, the results of the validator's assessment through a questionnaire with the 30 items showed that the final score was very appropriate with the score of 89.
\end{abstract}

Keywords: augmented reality, learning application, smartphone, vocational high school

\section{INTRODUCTION}

Vocational secondary education is one of education models in Indonesia that has special characteristics. It is realized in the form of a Vocational High School (VHS) education level. The purpose of vocational education is stated in the Indonesian Government Regulation No. 19 of 2005 which explains the aims of vocational education is to provide students with the ability to do certain types of work. In its application, the development of vocational skills is carried out through productive learning, namely study groups that contain special expertise packages according to the majors selected by students in VHS. To achieve this expertise, a competency to be specifically taught is required. Mastery of competence for students is very important to prepare them face the industrial world. However, the teaching learning in the schools sometimes encounters obstacles along with the process, because students do not understand the materials delivered by the teachers [1].

Based on the observations in several Vocational High Schools in Pekanbaru City in the field of computer engineering and network expertise, there are several problems in the implementation of vocational productive learning including inadequate learning facilities, and poor learning management and monitoring in the laboratory. If productive learning is not effective, it will impact on the students' achievement.

Inadequate laboratory equipment for students to do productive learning which one of the problems identified was urgent to be solved. In general, laboratories in Vocational Schools located in Pekanbaru City do not accommodate each student with one unit of computers. This situation is a barrier for students in achieving vocational competencies. To overcome the problem, the solution of providing the students with new laboratories is not the answer since the 
problem is not only caused by poor facilities and infrastructure but also poor management and monitoring of laboratory works [2]. The use of learning technology can be more suitable alternative solution for the problem. At present, everyone has the ability to access information through the digital world. In educational fields, this certainly makes it easy for students to find a variety of relevant and up-to-date learning resources[3][4]. Learning resources can be in the form of digital media, computer-based interactive multimedia to mobile-based learning media.

Mobile-based learning media are learning media embedded in mobile telecommunications devices, especially those with smartphones. The forms of learning technology displayed in mobile devices can be e-books, games and simulations. Simulation-based learning media aims to bring students to be able to feel learning in accordance with the actual situation. A virtual laboratory is often associated with learning that uses Information and Communication Technology (ICT) based simulation media. Virtual laboratory media are used as a substitute for practical activities that cannot be conducted by students because of the limitations of laboratory equipment or difficult demonstrations. The type of virtual laboratory used in learning is virtual computer-based laboratory simulation. Studies related to optimizing the use of laboratory-based mobile learning by Arista \& Kuswanto and Wachid \& Majid [5][6] claimed that mobile-based learning can provide convenience for students to access learning outside the school hours and allow flexible practicum. The simulation can be made in the form of games, virtual laboratories, animation and augmented reality technology.

Augmented Reality (AR) is the latest technology in the development of smartphone applications. It is an interactive experience of a real-world setting in which real-world objects are improved by computer-generated perceptual data, sometimes across various sensory modalities, including visual, auditory, haptic, somatosensory and olfactory [7]. Augmented Reality (AR) has the potential to be used in the learning and education process in schools [8]. The advantage of using augmented reality technology is the 3D animation visualization feature. 3D visualization technology is used while the visualization of the effects of superimposition is real and virtual realities and students' learning turn into the subject [9].

Augmented Reality (AR) certainly can be a solution in the implementation of interesting learning. However, no reference has been found related to the use of AR technology to support the learning process in vocational education in Indonesia. Therefore, with the different characteristics of vocational education with general education, it is necessary to develop an ARbased learning technology that can be implemented for productive learning in vocational education.

This study was carried out with the aim of producing a multimedia-based learning application product by applying augmented reality technology. The learning application developed was then tested for validity from the aspects of media development and vocational productive learning materials. The results of the study that have been carried out can be used as a reference for learning resources to overcome the problem of the low students' achievement in vocational competencies in Indonesia.

\section{METHOD}

This study was research and development. It is a research method used to create products and test the effectiveness of products that have been developed. The expected result from the implementation of this study is a prototype of Augmented 
Reality based learning technology that has been tested in the vocational learning process.

In the development of learning media applications, the waterfall method was used. The waterfall method is considered relevant in achieving the goal of producing a reliable and effective application. The method used starts from analysis to application that can be used in a learning process [10]. The stages of development with the waterfall method is illustrated in Figure 1.

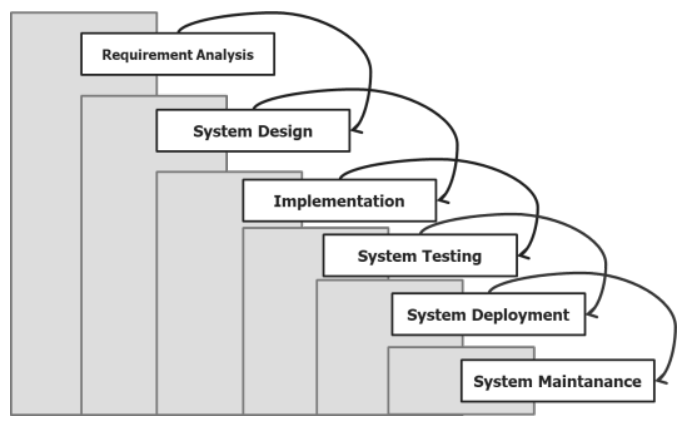

Figure 1. The Stages of Waterfall Method

In the stage of needs analysis, the activities carried out were observations related to the characteristics of $\mathrm{AR}$ media needed in accordance with the conditions and demands of the applicable educational curriculum. Data needs analysis were obtained through observation of the learning process and interviews with teachers related to the characteristics of required learning materials. In the stage of system design, system design in terms of appearance and flowchart was developed with reference to the results of needs analysis. Views in this case include interface design and color selection, display of $3 \mathrm{D}$ objects in the form of augmented reality. In the programming flowchart, other than the media programming algorithm developed, the design was done by modeling the system. The system model used in this study is the Unified Modeling Language (UML). In the implementation stage, the media was developed using supporting software presented in Table 1.
Table 1. Supporting Software for Application Development

\begin{tabular}{rll}
\hline No & Software & \multicolumn{1}{c}{ Function } \\
\hline 1 & Unity & $\begin{array}{l}\text { Producing 3D animation } \\
\text { Generalizing augmented } \\
\text { marker }\end{array}$ \\
2 & Vuforia & $\begin{array}{l}\text { Producing Smartphone- } \\
\text { based Media Application }\end{array}$ \\
& $\begin{array}{l}\text { Android } \\
\text { Studio }\end{array}$ & \\
\hline
\end{tabular}

Testing was done by alpha and beta testing methods. Alpha testing was carried out by software experts, learning media, learning technology and curriculum experts. The development of this application took approximately 6 months. This media was developed with the characteristics of a 3D lab simulation on PC assembly productive material for the $10^{\text {th }}$ grade students of Vocational High School.

The data analysis used in this study is descriptive quantitative. Data that has been obtained through alpha and beta testing were analyzed using descriptive statistics. The quantitative data used in the questionnaires of media validation, material, software design experts and learners' responses are expressed in the Likert scale described in Table 2 [11]. The score data that has been obtained was then converted into the form of a scale of 4 which can then be interpreted in descriptive as in Table 3.

Table 2. The Scale for the Questionnaires

\begin{tabular}{cc}
\hline Score & Interpretation \\
\hline 4 & Very Feasible \\
3 & Feasible \\
2 & Infeasible \\
1 & Very Infeasible \\
\hline
\end{tabular}

Table 3. Categories for the Feasible Scale

\begin{tabular}{cc}
\hline Score Interval & Category \\
\hline $\mathrm{X}>\mathrm{Mi}+1.5(\mathrm{SDi})$ & Very Feasible \\
$\mathrm{Mi}<\mathrm{X}<\mathrm{Mi}+1.5(\mathrm{SDi})$ & Feasible \\
$\mathrm{Mi}-1.5(\mathrm{SDi})<\mathrm{X}<\mathrm{Mi}$ & Infeasible \\
$\mathrm{X}<\mathrm{Mi}+1.5(\mathrm{SDi})$ & Very Infeasible \\
\hline
\end{tabular}




\section{RESULTS AND DISCUSSION}

Augmented reality-based media simulation allows students to interact with learning material visually and in more detail [12], [13]. Independently, students can actually find various learning media based on augmented reality simulation through play stores if they want to use the mobile learning model. However, the students face some problems after downloading the media regarding the incompatibility of material content in the learning media with the guideline of the standard curriculum in VHS. Therefore, the learning media that meets the curriculum guidelines was designed.

To achieve media in accordance with curriculum guidelines, needs analysis was carried out through the curriculum and teaching and learning process in the classroom. The results of needs analysis discovered that $\mathrm{AR}$ media required to be designed to achieve instructional goals in PC assembly materials. In addition to the achievement of instructional objectives, the media is designed to be used as a substitute for equipment that is not permitted to be taken home, thus the AR media needs to be designed to be able to display $3 \mathrm{D}$ animations and simulations of PC components and PC assembly procedures.

In addition to simulation media, the media developed needs to be supplemented by exposure to materials and a collection of practice questions to support the independent learning process that can be carried out by students. To achieve these needs, the next design is the storyboard design of the AR media application. The purpose of storyboard design was to guide the game development flow [14], [15].

After the storyboard was designed according to the needs analysis, the interface design was then carried out through the coding process and implementation in the form of digitization through computer devices. The device used to design the display of games in this study was 3D unity. It can also be used to design interfaces from the media applications. The appearance of the $3 \mathrm{D}$ animation display design process can be seen in Figure 2.

After the application display was designed, the production of AR objects was carried out by applying the IEC algorithm. The IEC algorithm is an iteration of the development of 3D objects based on augmented reality through a pattern recognition process [9]. The algorithm in question can be seen in Figure 3.

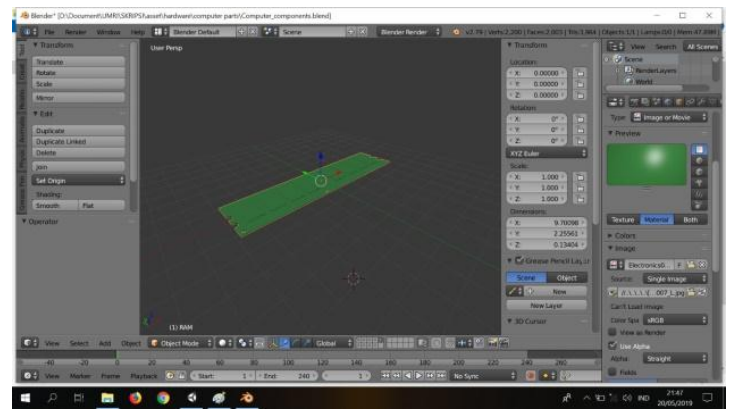

Figure 2. 3D Animation Design

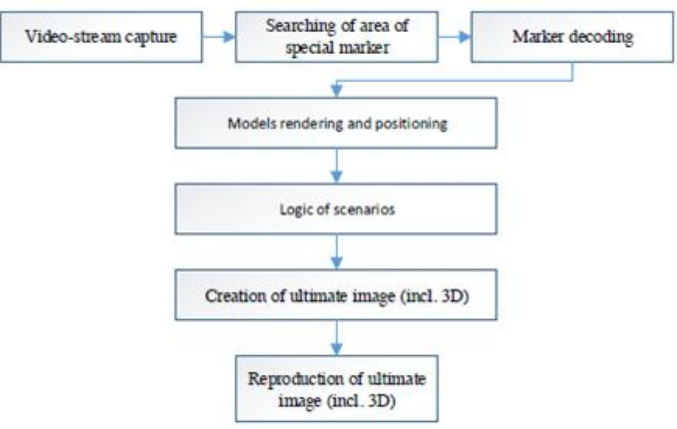

Figure 3. IEC Algorithm

For the production phase through implementation through software, the development scheme was implemented by using Unity 3D. Furthermore, the object that has been produced in the form of animation was then generalized in the form of a marker using Vuforia. The scheme is presented in Figure 4.

From the algorithm design applied, the next steps taken were the implementation of 3D animation production and the production of patterns or barcodes 
that would be used as 3D animation visualization media. The $3 \mathrm{D}$ animation designed was then planted in the form of a card equipped with a barcode as a source of 3D animated images that would be a source of learning.

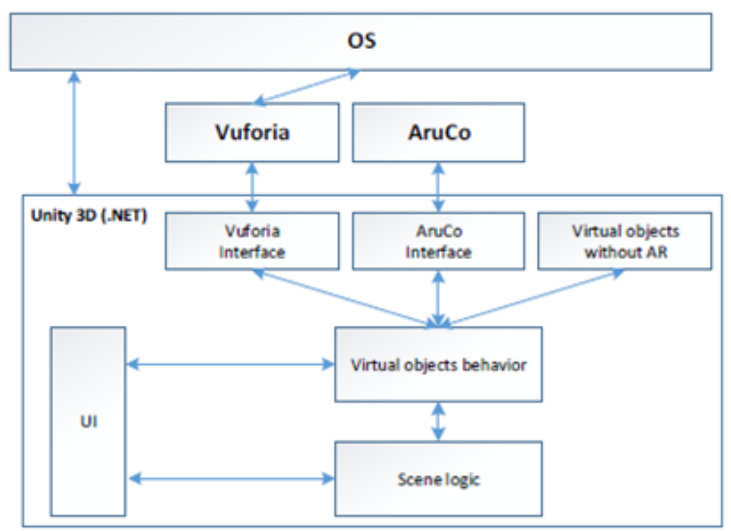

Figure 4. Production Stages of Augmented Reality Object

The development of learning media applications was then carried out by applying the storyboard design results and the design of programming algorithms. The development for the implementation of the application was done in some stages. For basic media design, it was done by using Unity to produce 3D applications, homepage, platforms and animations that become augmented reality. Figure 5 explain the AR operational instruction.

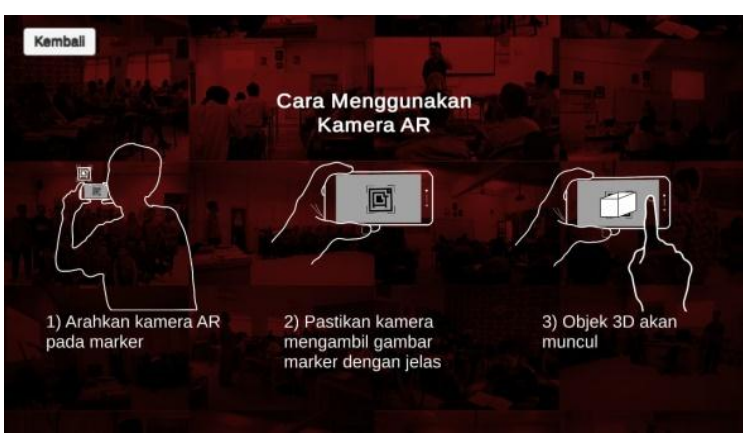

Figure 5. Augmented Reality Operational Instruction

After the application has been designed and implemented, according to the procedures implemented, testing of the media was carried out. Testing was done by applying alpha and beta testing. At the alpha testing stage, testing was done by validating the applications that had been developed. The measurement of application validity is done to get data about the operation function and appearance of the application. The validated aspects in this application are aspects of media and materials. Validation was carried out by experts who have competencies in their respective fields. In media validation, the validators consisted two lecturers in the field of multimedia programming and design. In the material validation, the selected validators were one teacher in computer and network engineering and one lecturer in informatics education.

Validation was carried out by experts by operating applications that have been developed and then providing an assessment through a questionnaire. From the validation results, revisions were made according to the suggestions from every validator.

Analysis of data from the results of the validation that has been carried out is then categorized in the form of scores of 0 to 100. The predetermined scores are further divided into 4 categories in Table 4.

Table 4. Determined Score Category

\begin{tabular}{lcc}
\hline No & Score Interval & Category \\
\hline 1 & $75.00 \leq \mathrm{x} \leq 100$ & Very Feasible \\
2 & $50.00 \leq \mathrm{x} \leq 75$ & Feasible \\
3 & $25.00 \leq \mathrm{x} \leq 50$ & Infeasible \\
4 & $0.00 \leq \mathrm{x} \leq 25$ & Very Infeasible \\
\hline
\end{tabular}

Validation assessment from each expert is adjusted to the indicators contained in the assessment instrument. For assessment by media experts, the assessment indicator items consist of 32 items of statements. The details of each aspect are described in Table 5. The results of the final validation provided by media experts for each aspect can be seen in Table 6 . 
Table 5. Aspects for Media Validation

\begin{tabular}{llcc}
\hline No & \multicolumn{1}{c}{ Aspect } & Code & $\begin{array}{c}\text { Indicator } \\
\text { Item }\end{array}$ \\
\hline 1 & Application Design & A1 & 10 \\
2 & Software Engineering & A2 & 10 \\
3 & Media Integrity & A3 & 5 \\
4 & Media Practicality & A4 & 7 \\
\hline
\end{tabular}

Table 6. Results of Media Validation

\begin{tabular}{|c|c|c|c|c|c|}
\hline \multirow{2}{*}{$\begin{array}{l}\text { Code } \\
\text { Aspect }\end{array}$} & \multicolumn{2}{|c|}{$\begin{array}{l}\text { Media } \\
\text { Expert }\end{array}$} & \multirow[t]{2}{*}{ Aver. } & \multirow[t]{2}{*}{ Score } & \multirow[t]{2}{*}{ Category } \\
\hline & 1 & 2 & & & \\
\hline A1 & 32 & 34 & 33 & 82.5 & $\begin{array}{c}\text { Very } \\
\text { Appropriate }\end{array}$ \\
\hline $\mathrm{A} 2$ & 30 & 32 & 31 & 77.5 & $\begin{array}{c}\text { Very } \\
\text { Appropriate }\end{array}$ \\
\hline A3 & 18 & 16 & 17 & 85 & $\begin{array}{c}\text { Very } \\
\text { Appropriate }\end{array}$ \\
\hline A4 & 25 & 26 & 25.5 & 91 & $\begin{array}{c}\text { Very } \\
\text { Appropriate }\end{array}$ \\
\hline \multicolumn{3}{|c|}{ Average } & & 84 & $\begin{array}{c}\text { Very } \\
\text { Appropriate }\end{array}$ \\
\hline
\end{tabular}

The validation process was done twice by revising the results of validation in the first stage. The comparison data from the results of validation conducted by media experts is presented in Figure 6.

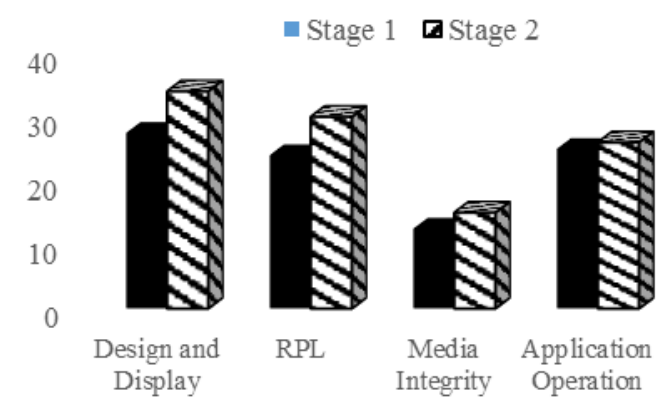

Figure 6. Comparison of the Result of Media Expert Validation

Based on the data that has been analyzed, it can be described that as a whole, all aspects of the media validation process can be grouped in very suitable constructive categories. Partially it can be stated that the practical aspects of the media have the highest conversion score with a score of 91 above the overall average of 84 .

For the Recognition of Prior Learning (RPL) aspect, the score is lower than the other aspects. Based on the validation data, the score on the RPL aspect is at the score of 3 for 7 indicators and 4 for 2 indicators and 2 for 1 indicator. The indicator from the aspect of RPL that gets score 2 is the display of animation that can be changed dynamically by the user. While those that get the score of 4 indicators are the novelty of programming techniques and the access speed of 3D animation display in augmented reality developed. For assessment by material experts, the assessment indicator items consist of 25 statement items. The details of each aspect can be described in Table 7.

Table 7. Aspects for Materials Validation

\begin{tabular}{cccc}
\hline No & \multicolumn{1}{c}{ Aspect } & Code & $\begin{array}{c}\text { Indicator } \\
\text { Item }\end{array}$ \\
\hline 1 & $\begin{array}{l}\text { Cognitive } \\
\text { Content } \\
2\end{array}$ & B1 & 7 \\
Vocational \\
Competence \\
3 & $\begin{array}{l}\text { Presentation of } \\
\text { Information } \\
\text { Evaluation } \\
\text { Technique }\end{array}$ & B3 & 5 \\
\hline
\end{tabular}

The final results of a total of two validation activities on the material design that have been carried out by media experts for each aspect can be seen in Table 8 .

Table 8. Result from Material Validation

\begin{tabular}{|c|c|c|c|c|c|}
\hline \multirow[t]{2}{*}{$\begin{array}{l}\text { Code } \\
\text { Aspect }\end{array}$} & \multicolumn{2}{|c|}{ Learning } & \multirow[t]{2}{*}{ Aver. } & \multirow[t]{2}{*}{ Score } & \multirow[t]{2}{*}{ Category } \\
\hline & 1 & 2 & & & \\
\hline B1 & 23 & 27 & 25 & 89.3 & $\begin{array}{c}\text { Very } \\
\text { Appropriate }\end{array}$ \\
\hline B2 & 29 & 29 & 29 & 90.6 & $\begin{array}{c}\text { Very } \\
\text { Appropriate }\end{array}$ \\
\hline B3 & 18 & 16 & 17 & 85 & $\begin{array}{c}\text { Very } \\
\text { Appropriate }\end{array}$ \\
\hline B4 & 17 & 19 & 18 & 90 & $\begin{array}{c}\text { Very } \\
\text { Appropriate }\end{array}$ \\
\hline & & & & 89 & $\begin{array}{c}\text { Very } \\
\text { Appropriate }\end{array}$ \\
\hline
\end{tabular}


Figure 7 presents the comparative data from the results of validation carried out by experts in learning materials in stages 1 and 2.

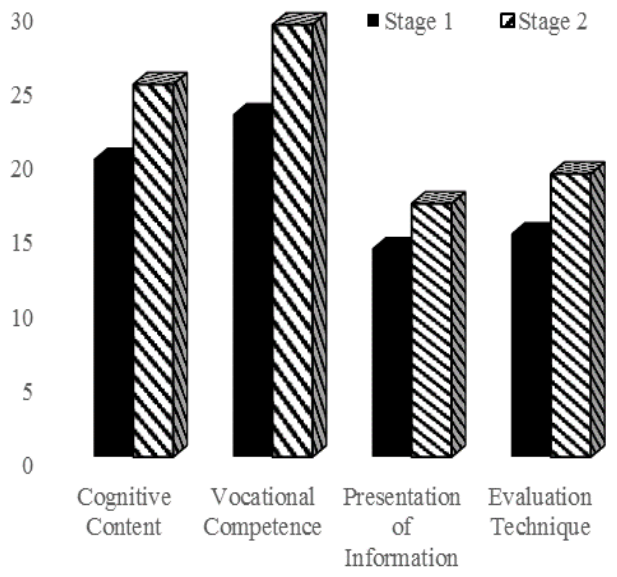

Figure 7. Comparation of the Result of Material Expert Validation

If it is viewed from the graph, it appears that there are changes that tend to increase in every aspect of the learning material validation process. In the aspect of vocational competence, the validation score has a fairly high increase in the validation of the first stage to the second stage. The increase margin is 6 points, from 23 to 29 .

Based on the results of the tests and the review of the development of the media experts, it shows that the application is very appropriate.

From the results of the validation by the learning material experts, it can be indicated that the presentation and development of learning materials are categorized as valid. In the development of a learning media application, the materials developed must be able to provide improvement of students' enthusiasm [16]. Therefore, the displayed materials is not only text but it is also equipped with attractive images, videos and AR animations. The augmented reality animation displayed is designed to resemble the original model. Animation of augmented reality has the purpose that a real model can be displayed in a virtual form [17].
In addition to the display of materials, the aspects of learning presentation are expected to present an innovation. Learning with augmented reality-based media can provide added scores to the learning climate. These scores include the latest technology, cognitive challenges and managerial abilities in the learning process [18]. When compared with the results of validation and development, it can be seen that the learning aspect has a score of 25 of the maximum total score of 28 . Besides the material and the learning process, the evaluation aspect is also presented in the learning application that has been developed. Evaluation is a part that must be fulfilled when designing a learning media through the evaluation menu.

The vocational competence achieved by students at the vocational education level consists of conceptual competencies, procedural competencies and interpretation competencies [19]-[21]. Therefore, the application designed has been equipped with learning materials and features to achieve the expected profile of vocational competence.

The derivative of the profile displayed in the application as in conceptual competence in the application. Media with the latest content and basic and applied knowledge of PC assembly materials was designed. In the realm of procedural competence, the expected result is students can understand the concept model of knowledge that has been given. The model can be displayed through AR animations for facilitating students understand the structure, characteristics and appearance of each part of the PC device that can be seen virtually from all sides.

When a student has been able to combine conceptual competencies and procedural competencies, students are able to interpret the learned theory [22], [23]. Interpretation competence in vocational education is a competency construction that is required so that graduates from vocational education have skills in accordance with the 
theories taught in the school. In the developed application, the interpretation construction of competencies is built through the presentation of materials and the appearance of the model of each PC device being studied in accordance with the curriculum. Then after going through the materials and 3D simulation, students can work on the practice questions contained in the application that has been developed.

In terms of the presentation of learning, the presence of the developed application named AugWare can certainly support a learning model that can combine learning in the classroom with distance learning or the so-called blended learning. Blended learning is a learning model that combines classroom learning and computerassisted learning in the form of web-based learning or application based learning [24], [25]. The leading aspect of the AugWare application in presenting the blended learning model can be seen in the application ability to make students explore device forms in a PC through 3D animation models.

Problems in the process of vocational learning activities related to the lack of infrastructure and time constraints can be overcome by the advantages possessed by the AugWare learning application that has been developed. In this application, students can learn in the process of recognizing, identifying and analyzing various PC devices through AR based simulations. Furthermore, students can learn about the PC assembly process through the virtual tutorial provided. The purpose of this AR technology is to solve the students' problems regarding the limitations of devices that students may have and the short practicum time obtained by students at school.

Augmented Reality (AR) technology has specificity from the didactic process presented. Didactics presented are the ability of this technology to connect the real appearance with virtual elements and display them in virtual forms [26]. Through AR technology, simulations that are presented become virtual and real in nature, not only in the form of 2D animation. Therefore, students can observe the PC assembly process from various sides simultaneously.

\section{CONCLUSION}

From the results of the development that has been described, it can be concluded that the technology of $\mathrm{AR}$ as the latest technology in the development of computer graphics can be developed to produce 3D animations that can support education. Augmented Reality (AR) technology can be integrated in a learning application that is equipped with materials and evaluation. The development of application to support productive learning on PC assembly materials can be developed using a combination of Unity, Blender and Vuforia software. The algorithm used to develop the 3D augmented reality model used is IEC. Learning application that has been developed can be operated using an Android-based Smartphone. The application developed is then called AugWare. The validity test of the AugWare application is done on the aspects of developing media and learning materials. From the results of the validity test by media experts, all aspects are categorized as very appropriate or very high validity. For the validation results by material experts, it can be concluded that the overall aspects of developing learning materials are very suitable for the needs of productive learning. However, the development carried out has not yet been tested to the user to measure the effectiveness of its use. It is recommended for further research to measure the effectiveness of the media in the process of vocational productive learning. The method suggested in productive learning trials is a quasi-experimental method or classroom action research. The developed media can also be used as research materials to do 
improvements related to the development of more recent materials and 3D display.

\section{ACKNOWLEDGMENT}

This research was funded by the Ministry of Research, Technology and Higher Education of the Republic of Indonesia through Research Grant with the contract number 05/PRJ/II.3.AU/F/7/2019.

\section{REFERENCES}

[1] N. W. A. Majid and P. Sudira, "Proses perolehan kompetensi TIK melalui program praktik industri siswa SMKN 2 Pengasih Kulon Progo," J. Pendidik. Vokasi, 2017.

[2] H. F. Hanafi, C. S. Said, M. H. Wahab, and K. Samsuddin, "Improving Students' Motivation in Learning ICT Course with the Use of A Mobile Augmented Reality Learning Environment," IOP Conf. Ser. Mater. Sci. Eng., vol. 226, no. 1, 2017.

[3] C. H. Chen, C.-H. Ho, and J.-B. Lin, "The Development of an Augmented Reality Game-based Learning Environment," Procedia - Soc. Behav. Sci., vol. 174, pp. 216-220, 2015.

[4] M. Pischetola, "Digital Media and Learning Evolution: A Research on Sustainable Local Empowerment.," Glob. Media J. Am. Ed., vol. 11, no. 18, pp. p1--11, 2011.

[5] F. S. Arista and H. Kuswanto, "Virtual physics laboratory application based on the android smartphone to improve learning independence and conceptual understanding," Int. J. Instr., vol. 11, no. 1, pp. 1-16, 2018

[6] N. Wachid and A. Majid, "Development of the Traditional Digital Games for Strengthening Childhood Verbal Skill," J. Pendidik. Vokasi, vol. 9, no. 1, pp. 75-82, 2019.

[7] P. Schueffel, The Concise Fintech Compendium. Fribourg: School of Management Fribourg, 2017.
[8] D. Nincarean, M. B. Alia, N. D. A. Halim, and M. H. A. Rahman, "Mobile Augmented Reality: The Potential for Education," Procedia Soc. Behav. Sci., vol. 103, pp. 657664, 2013.

[9] S. Sannikov, F. Zhdanov, P. Chebotarev, and P. Rabinovich, Interactive Educational Content Based on Augmented Reality and 3D Visualization, vol. 66. Elsevier Masson SAS, 2015.

[10] R. S. Pressman, Software Quality Engineering: A Practitioner's Approach. 2014.

[11] N. N. Knupfer, "Visualizing Instructional Design: The Potential of Dynamic Computer Presentations," Annu. Conf. Int. Vis. Lit. Assoc., 1997.

[12] H. Kato, "Introduction to Augmented Reality," J. Inst. Image Inf. Telev. Eng., vol. 66, no. 1, pp. 53-56, 2012.

[13] F. Torres, L. A. N. Tovar, and M. C. Egremy, "Virtual Interactive Laboratory Applied to High Schools Programs," Procedia Comput. Sci., vol. 75, no. Vare, pp. 233-238, 2015.

[14] G. J. Hwang, H. Y. Sung, C. M. Hung, and I. Huang, "A learning style perspective to investigate the necessity of developing adaptive learning systems," Educ. Technol. Soc., vol. 16, no. 2, pp. 188-197, 2013.

[15] M. M. Zarzuela, F. J. D. Pernas, L. B. Martínez, D. G. Ortega, and M. A. Rodríguez, "Mobile serious game using augmented reality for supporting children's learning about animals," Procedia Comput. Sci., vol. 25, pp. 375-381, 2013.

[16] Á. Di Serio, M. B. Ibáñez, and C. D. Kloos, "Impact of an augmented reality system on students' motivation for a visual art course," Comput. Educ., vol. 68, pp. 586-596, 2013.

[17] J. Bacca, S. Baldiris, R. Fabregat, Kinshuk, and S. Graf, "Mobile Augmented Reality in Vocational Education and Training," Procedia Comput. Sci., vol. 75, no. Vare, pp. 49-58, 2015.

[18] M. Dunleavy, C. Dede, and R. 
Mitchell, "Affordances and limitations of immersive participatory augmented reality simulations for teaching and learning," J. Sci. Educ. Technol., vol. 18, no. 1, pp. 7-22, Feb. 2009.

[19] V. Deutscher and E. Winther, "Instructional sensitivity in vocational education," Learn. Instr., vol. 53, pp. 21-33, Feb. 2018.

[20] F. Achtenhagen and E. Winther, "Workplace-based competence measurement: Developing innovative assessment systems for tomorrow's vet programmes," J. Vocat. Educ. Train., vol. 66, no. 3, pp. 281-295, 2014.

[21] K. Reiss, "Competence development - A key concept of higher education," Empir. Res. Vocat. Educ. Train., vol. 4, no. 1, pp. 73-76, 2012.

[22] V. K. Klotz, S. Billett, and E. Winther, "Promoting workforce excellence: Formation and relevance of vocational identity for vocational educational training," Empir. Res. Vocat. Educ. Train., vol. 6, no. 1, pp.
1-20, 2014.

[23] V. K. Klotz, E. Winther, and D. Festner, "Modeling the Development of Vocational Competence: a Psychometric Model for Economic Domains," Vocat. Learn., vol. 8, no. 3, pp. 247-268, Oct. 2015.

[24] P. B. Herlandy and M. Novalia, "Penerapan e-Learning pada Pembelajaran Komunikasi dalam Jaringan dengan Metode Blended learning Bagi Siswa SMK," J. Educ. Inform. Technol. Sci., vol. 1, no. 1, pp. 24-33, 2019.

[25] P. B. Herlandy, D. E. Ratna, and E. Ismanto, "Pengembangan Media Pembelajaran Dengan Adobe Flash Pokok Bahasan Komunikasi Dalam Jaringan Untuk Kelas X SMK," vol. 3, no. 1, pp. 29-39, 2019.

[26] T. Jeřábek, V. Rambousek, and R. Wildová, "Specifics of Visual Perception of the Augmented Reality in the Context of Education," Procedia - Soc. Behav. Sci., vol. 159, pp. 598-604, 2014. 